\title{
Religious Consciousness in Mangrove Conservation Efforts in the North Coast of Java
}

\author{
Asma Luthfi \\ \{asma_luthfi@mail.unnes.ac.id \\ Universitas Negeri Semarang, Indonesia
}

\begin{abstract}
Mangrove conservation activities undertaken Bedono community in the aftermath of the tidal flood that inundated their guided by Islamic consciousness that they believe. The purpose of this study is describing the religious consciousness in mangrove conservation activities undertaken by the community of Bedono. This research uses qualitative research based data collection through observation, interviews and documentation study. Data processing method starting from data collection, data reduction, data presentation, and conclusion. Verification of data using a triangulation method. The results showed that: (1) The existence of the tomb guardian K.H.Abdullah Mudzakkir is one aspect that makes them still live in the area and planted mangroves. (2) Religious Consciousness underlying mangrove conservation activities is to acquire awareness of personal safety and the environment, maintain the sustainability of religion, and maintain the safety of the environment and property which is a medium for people to worship. (3) The function of religion in mangrove conservation activities are metatechnology and worship function. This study also highlights the religious consciousness that underlies Bedono mangrove conservation in the village have also experienced the dynamics in line with government policy, aid from foreign donors, and the commodification of disasters through mangrove and religious tourism.
\end{abstract}

Keywords: Mangrove Conservation, Religious Consciousness, Northern Coast of Jawa.

\section{Introduction}

One of the biggest threats that hit the world today is global warming which causing extreme climate change [1]. It not only affects the ecological devastation, but also the sustainability of human life [2][3]. This problem seems to be a law of causality cause global warming phenomenon actually started from the ecological damage that occurred in various parts of the world as a result of human behavior that are no longer considering the balance of nature and exploitation of natural resources. As was the case in Indonesia, environmental damage has occurred in almost all regions. Although it is one country that has the largest tropical forests as the lungs of the world, but Indonesia is also a country that has a high level of environmental degradation due to human exploitating activities.

In the coastal areas, environmental damage is caused by natural and non-natural aspects. In natural aspect, the damage occurred due to natural factors, the environment, and climate such as abrasion, erosion, deposition and seawater intrusion, while the damage to non-natural aspect occur because of human behavior like the deforestation of mangroves, construction of 
pier / harbor, and the reclamation [4]. For example, port development and the reclamation can damage coral reefs from the ecological wealth of the beach. In this case, reefs may be damaged due to anthropogenic (human activity) and non-anthropogenic (natural factors)[5]. In the case of mangrove forests, the damage is influenced by economic factors because many people who live around the coast explore and change its function to increase the necessities of life. This can be seen in the clearing of new ponds and the use of mangrove wood for building materials [6].

Ecological degradation of coastal areas brought new problems for society such as coastal erosion, flooding tide $(r o b)$, and diminishing resources into coastal livelihoods. In Central Java, some beaches are already experiencing severe environmental damage and become major threat to the sustainability of the lives of people there [7][9]. As in the village of Bedono, Demak, rob disaster has struck the community in the last 20 years because of the overflow of seawater into human settlements. This makes a lot of people have to be relocated as their homes were unfit for occupancy and their hamlets have become part of the oceans due to tidal flooding [10]. Their land ponds and several public facilities are inundated with seawater, so it can no longer function. These conditions caused many people lost their jobs and had to switch professions [11]. Nevertheless, some of them who still living in this severe damage area chose to survive in their village by raising their homes every year. They chose to live in the village of Bedono for their religious and cultural strong ties with their ancestral village.

Tidal flood which had drowned two hamlets in Bedono is one of the worst environmental disasters in Central Java. This makes the public, government and private organizations whom concerned about the environment, conducted a series of activities to decrease tidal flood threat and to safeguard human life and the environment. One of the efforts that have been made in the last five years is conservation land with seeding and planting of mangrove trees around the beach of Bedono. Seeding and planting of mangrove trees, which were the result of cooperation between the government, NGOs and the community abroad, has successed. Mangrove trees have grown into a dense mangrove forest, reforestation initiatives and educational tourism by the public.

High community participation in mangrove conservation efforts cannot be separated from their awareness of the need for conservation of the environment so that they can save the village from extinction due to rob. Nevertheless, religious and cultural values also the aspects underlying conservation activities they do. In some regions, religious and cultural values have a considerable influence for the preservation of the environment [12][17]. Similar conditions can be found in the village of Bedono which the majority of its people are Muslims. They achieved a kind of theological belief that disaster on land and at sea are part of human activity, hence, it is necessary to anticipate the human behaviour as well. Moreover, in one of the hamlets that experienced rob severe enough, there is a tomb of guardian of God (Waliyullah), a holy cleric who spread Islam in Demak and surrounding areas. As a Muslim society that still sacralized guardian figure in their lives, the people of Bedono always keep and care for the existence of the tomb. Aside from being a religious symbol, they also enable the tomb as a place to bertawashul so that they can be given the ease and safety in their lives. Therefore, this article aims to explain the religious consciousness in mangrove conservation efforts in the Village of Bedono as activities to save the environment and human life in a sustainable manner. 


\section{Methodology}

This is a qualitative research that explore the data descriptively and inductively. This research is a case study which is a deep study on an individual, a group, an organization (community), a program activity, or social situations within a certain goal weeks to obtain a description of a full and in-depth. The location of this research is Bedono Village, District Sayung, Demak. There are many reasons for choosing this village as research areas. First, this village is a village on the North Coast of Java which severely affected by the tidal floods. Second, mangrove conservation program has been carried out in this village and showing results quite siginifkan. Third, people in this village are the Muslim community who has faith and religious awareness in environmental preservation and conservation of mangroves. Subjects in this study were residents of the village community Bedono Sayung District of Demak district. Data and information are distinguished into two parts, namely data/information and the data of primary/secondary information. The data is extracted with a few steps, ie, participatory observation, in-depth interviews, and the study of literature. Data are analyzed using qualitative descriptive analysis. While the process of analysis using an interactive model that through the several processes: the data collect, reduction and presentation of data, and the conclusion. Thus the analysis of the data collection activities, and the process cycles until the study is completed.

\section{Religious Consciousness in Mangrove Conservation Activities}

Bedono village is a village in Kabepaten Demak, Central Java, which are relatively close to the city of Semarang. From the village Bedono, rows of large ships, both passenger and freighter ship anchored in the port of Tanjung Emas can be seen clearly. The distance to the city of Semarang is only about $15 \mathrm{~km}$ while the distance to the capital of Demak about $26 \mathrm{~km}$. It is directly adjacent to Java sea does not make Bedono as isolated villages. This is because access to good roads and the distances between villages that are relatively close. The distance to the farthest village village about $3 \mathrm{~km}$, the district capitals around $2 \mathrm{~km}$, and the regency capitals about $18 \mathrm{~km}$. This condition makes the villagers Bedono have high mobility and can come and go out of the village to work.

The population in the village of Bedono in 2016 of 3.343 people consisting of 1.668 men and 1.675 women. With this amount, the village of Bedono occupies a total area of 551.673 ha. The total area consists of dry soil in the form of the yard and the building has an area of 61 ha and wetlands such as ponds covering an area of 490.673 ha. Dry ground area narrower than the wet ground has occurred in the past two decades due to the surge of sea water that inundated many human settlements.

Traces of human settlements were submerged in sea water is partially used for the pond, some into the sea and partly also mangrove trees that now grow in abundance. Monographs of Bedono Village mention that existing protected forest in the village has an area of 166.876 ha Bedono which the majority of mangrove plants. In addition, the land use is also used for sports fields covering an area of 10.590 ha, recreational park area of 5 hectares, the cemetery area of 2,021 hectares, Masjid / mosque / Violating area of 0.40 hectares, education facilities covering an area of 1.50 hectares, and health facilities measuring $0,02 \mathrm{Ha}$. By this means, the society can perform everyday social activities despite limited dry soil conditions. 
As people who inhabit the villages located on the north coast of Java, villagers Bedono mostly working in the fisheries and marine sector. Based on data from monographs village in 2015, the villagers Bedono the fishermen as much as 271 people (including fish farmers), labor industry as many as 250 people, construction workers as many as 155 people, merchants as 68 , services of transport as 6 people, civil servants as 1 people and soldiers/police as 1 person.

From the data type of the above work can be seen that the fisherman is the work of the most widely hailed by the public Bedono. However, this is not a fishing profession because the majority of people who are not fishermen are greater. The diversity of the people in the village Bedono profession cannot be separated from the geographical conditions of the area close to the city of Semarang. For example in the profession of industrial workers and construction workers, many practicing a profession most people are in the city of Semarang.

The village Bedono a society that still apply traditional values and religion in their lives. Community social activities that put togetherness and mutual cooperation can still be found there. Family ties are still quite closely in strengthening social ties more broadly. Nevertheless, a harmonious atmosphere is not running smoothly and without a hitch, because sometimes social conflicts such as family conflicts that characterize their social life. But the conflict did not last long because it can be addressed by each individual.

Rob or abrasion disaster that struck the village community Bedono since the last twenty years have led to many changes, both in ecological and socio-cultural. Ecological changes marked by the overflow of sea water that cause most of the land in the village of Bedono flooded by seawater. Even some hamlets as in Tambak Sari and Senik (Rejosari) already sunk and could not longer inhabited by citizens. Residents in these two villages had to be relocated outside the village they are considered safer than rob. Meanwhile, socio-cultural changes characterized by changes in the livelihood of the fishermen to industrial workers, social interaction which has begun tend individualist, and orientation of the earnings are mostly aimed at heightening their home location.

Coastal erosion that affects people in the village Bedono not a disaster that comes on suddenly with high waves as the tsunami disaster in Aceh. Rob occurs slowly but continuously. At first, only a yard flooded homes and residents a few centimeters, but gradually rising up to the citizens no longer able to block it because it immerses high half of their home. Damaywanti (2013) explains that abrasion in the village Bedono due five (5) factors, namely: subsidence (land subsidence), destruction of mangrove forests that act as a natural barrier beach from waves and sedimentation, damage caused hydrodynamic forces of waves, rising sea levels due to global warming, and the damage caused by human activities such as sand mining on the coast, making buildings jutting into the sea, and the opening of the pond do not take into account the state of the condition and location.

The five factors that cause abrasion in the village Bedono cause environmental conditions erode people and make access to them restricted economy. This condition makes them into account matters of economy. As the events are conducted by outsiders in the village, they did not want to leave their jobs so that some of these events should provide the replacement cost of their transportation. For them, the conditions are very difficult in Bedono in defending themselves and the environment to make them work harder to earn more

\subsection{Tomb K.H. Abdullah Mudzakkir: Between the Sacred and Concerns}

Bedono Village Society is a society that still get the direct influence of the symbols of Islam The Waliyullah Demak. Traces the historical development of Islam in Bedono can be 
seen from the tomb of K.H.Abdullah Mudzakkir which is one of the scholars of Muslim missionaries who settled in Bedono. During his life, K.H.Abdullah Mudzakkir much visited by the material from outside the village to learn the religion of Islam. Its presence in the community made Bedono always adhered to the moral values of Islam.

From monographs village in 2015 mentioned that the community totaling 3.343 people Bedono entirely Muslim. They generally adheres to the teachings of Islam that wing ahlussunnah wal Jama'ah and mass organizations affiliated with NU (Nahdlatul Ulama). For that, it is in the village of Bedono so prevalent their tahlilan and slametan. This is due to the appreciation and practice of their religion cannot be separated from the values of Javanese culture they have. Javanese cosmology that promotes harmony between the macrocosm (jagad gedhe) and mikrokosos (jagad cilik) is reflected in the religious rituals that they do, such as sea alms and other slametan ritual. In addition, they also have a very high respect against Waliyullah as saints who have glory (karomah). This attitude was expressed by always maintaining and protecting the tombs of the saints, as they did at the tomb in the village K.H.Abdullah Mudzakkir Bedono almost drowned by the sea tide.

Kyai Abdullah Mudzakkir's tomb is one of the religious sites which are still maintained by the community. Many people who come there, both from within the village and outside one to read al-Qur'an and prayed in front of the tomb of Kyai Abdullah Mudzakkir. Visitors who come not just one or two people, but several groups. They believed that Kyai Abdullah Mudzakkir is one of the scholars of Islamic religious broadcaster who has glory (karomah). With prayer or connector (washilah) to Kyai Abdullah Mudzakkir, they hope to get blessing for their salvation in this world and in the hereafter.

From the picture above can be seen that rob that struck the village of Bedono influence on the existence of the tomb of Kyai Abdullah Mudzakkir. Expanse of sea water which formerly was the settlement and paddy fields has made the location of the tomb of Kyai Abdullah Mudzakkir seemed like an island separated from the mainland. Electrical poles still stuck around the small road into land access to it. Former house walls had collapsed also decorate the landscape around the road leading to the tomb. From some of these objects, it can be imagined how the population is very crowded at the site before the disaster rob.

The existence of the tomb of Kyai Abdullah Mudzakkir which is currently located in the middle of the sea is maintained and restored by the residents who still live in the vicinity. In administrative, burial site is located in the hamlet of Pond sari majority was relocated in 19992000 to the village of Sidogemah and Purwosari. Nevertheless, there are six families who survived and did not want to be relocated. The sixth head of family still have sibling relationships and a distant relative of Kyai Abdullah Mudzakkir. Besides being the average of their profession there are fishermen, they also do not want to leave the tomb of Kyai Abdullah Mudzakkir, because they feel that it is their responsibility to guard the tomb of Waliyullah.

A sense of responsibility in guarding the tomb of Kyai Abdullah Mudzakkir is part of the consciousness of their religious beliefs. For them, guarding the tomb of Waliyullah is preserving Islamic values left by the Prophet Muhammad and scholars as the heir to the prophet. They believe that they can obtain ease in this life and the hereafter while maintaining the heritage of scholars, including the grave. For that, they were assisted by donations from outsiders always restore by raising the tomb of Kyai Abdullah Mudzakkir from drowning. In addition, they also take care of the environment surrounding the plant and rehabilitate mangrove. 


\subsection{Planting Mangrove, Reaping Rewards}

Mangrove rehabilitation process involves people from seeding to plant utilization in a variety of purposes. In the process of seeding, mangrove seedlings planted by the group into a polybag or on land owned by citizens. After the mangrove seedlings have grown, the plants are moved to a permanent place. At this stage of planting, carried out by individuals, both members of the marine mangrove group, as well as ordinary community members. Land planted mangrove coastal land that is basically not too deep. Because most of the land occupied by the former plant is the land area of housing that someone already has, then each owner involved in mangrove planting in their respective fields. From this mangrove planting, they were paid around 300 rupiahs each stem. Currently planted mangrove areas that have already spread to about 350 hectares along the coast of the village of Bedono.

In order for mangrove rehabilitation program can be run in a sustainable manner, the party formed a special group of people who oversee the passage of mangrove rehabilitation program. Lodging in the village Bedono, the group named Mangrove Marine Group that was founded in 2004. The group has a management structure, such as the chairman of the coordinating group activities mangrove, secretary noted the administrative affairs of the group, the treasurer who took care of the group's financial problems, and some members of the group. Currently, the structure of the group has been running for 2 (two) during the period. The first period of 2004-2014 and chaired by Mr. Yamrozi, while the second period began in 2014, chaired by Mr. Kharis. Community cooperation, Demak District Government, and OISKA International not only on mangrove rehabilitation but also the improvement of facilities and infrastructure damaged by abrasion, such as roads, bridges, places of worship and educational facilities.

In addition to cooperation with OISKA, Bedono rural communities also often receive visits and cooperation of mangrove planting of various agencies, such as CSR Companies, universities, government agencies, and local non-governmental groups. For them, the relationships and the cooperation of various parties is enough to help them to increase the number of mangrove trees of the land that remains. Until now, the plant has been grown dense mangrove and into the mangrove forest where creatures live and become a tourist destination people from outside the area.

At a glance, mangrove conservation activities undertaken by the community Bedono an activity that only secular (secular activities), or activities that are worldly and have no value transcendence. But if we look further into the social structure Bedono, it can be seen that the value of religion is one thing that underlies every activity they do, including on mangrove conservation activities. As rural communities are still promoting the values of religion, mangrove planting for environmental conservation is an activity that can give a reward. The concept of reward for them as Muslims are worldly activities that could be saving charity so that they can survive in the afterlife. Each activity is intended as worship and have a positive impact, and awards will be rewarded by Allah SWT. In this case, the villagers Bedono that all residents are followers of Islam, mangrove planting is one of the charities of their fields to worship and get the reward. This is because the mangrove planting can provide a positive impact on their survival as believers.

\subsubsection{Keeping Wellbeing and Descendants}

Keeping wellbeing is the first reason of religious communities that underlie Bedono's people participation in mangrove conservation. This is based on their beliefs as a Muslim that 
worship is a sacred activity that involves the unity between spirit and body, so both must be maintained so that the process of worship. Threats to personal safety felt by people Bedono when sea water flood occurs suddenly, even at night when they were asleep.

The threat to personal safety felt by the Bedono people due to the sea water is always felt by them, even though the flood waters have started to recede. This happens because often rob come upon unexpected. Not only themselves, but also the threats to the safety of children or their descendants as well they feel. In this case, the descent can be interpreted as the next generation to maintain, implement and transform the religious values that will remain there throughout the ages.

Rob danger that had sunk two hamlets in the village Bedono impact not only ecologically, but also social impact. For children, the ecological impact seen in homes and schools were flooded with sea water. This makes children reduce their comfort in the move, learn, and play. Meanwhile, the social impact for children can be seen in growing marginalization of some traditional games because of lack of land that could accommodate them. Cultural values and religion as solidarity, cooperation, honesty, and mutual aid as a moral message behind the traditional game is joined fade due to no longer play the traditional game. This condition is also a concern to conserve mangrove Bedono society that children still have open space to play.

\subsubsection{Keeping the Faith}

Keeping the faith is one of the motivations of religious communities in conserving mangrove Bedono. For Bedono society, preservation of the environment is part of their faith. Based on the al-Qur'an, they assume that the damage that occurs in Bedono because of human activity, both personal and structural. Therefore, to keep their faith and their existence as human beings who believe, they always tried to protect the environment, one of them by conserving mangrove.

Mangrove conservation activities they are doing is a manifestation of the way they strengthen their faith in God. By planting mangrove, they can keep God's earth and other creatures as trust and accountability form them as God's creation. Also their theological expression embodied in ritual slametan and sea alms (sedekah laut). Sedekah laut done every year as a manifestation of gratitude for their salvation from maritime disasters and blessings that they earned from the sea. If in past time sea alms is done by removing the head of goat or cow in the middle of the ocean, so this time the event has been abandoned. Sedekah laut they do now filled with public recitation by bringing cleric or religious scholars from outside the village. Food they had brought no longer discharged into the sea, but in a meal together at the location of the sedekah laut.

In addition the sedekah laut, society Bedono also do salvage event (slametan) usually done by each family. According to Geertz, slametan is a medium of bringing the various aspects of social life with personal experiences as well as keeping people from spirits that will disrupt their lives [18]. In Bedono, slametan they generally do accompany their life cycle such as pregnancy, birth, marriage, and death. As a ritual, slametan aims to connect them with God to avoid disaster, both in the physical aspect such as rob, or metaphysical aspect such as interference of spirits. 


\subsubsection{Maintain Environmental Safety and Possessions}

Environment is one of the most important aspects that affect the sustainability of human life. The whole process of human life including religious activities can not be done optimally if not supported by a conducive atmosphere. Environment that is meant here is the abiotic environment consisting of land, water, air and radiation. In terms of religion, mangrove conservation activities undertaken by the community Bedono not be separated from religious moral message to maintain the environment.

The importance of the environment for the survival of religion is a forum for religious activities undertaken by the community. For example, people Bedono used the field or yard of the mosque to perform communal rituals. But because this land has been inundated with seawater flooding, the ritual is transferred to the mosque or the village hall which is considered very narrow and cannot accommodate the number of people a lot. In addition, several mosques have also suffered the same fate with the houses, the rising sea levels that degrade the soil surface in the area of the mosque so that some of the mosque should be lifted. The mosque is elevated bury this by adding soil or ground and rebuild the mosque with the model stage. The remainder of the old building were raised by half again, so that the floor of the old buildings that are not used anymore, but instead the roof of the old building into a floor for the building of new mosques.

Rob disaster which occurred in the village Bedono not only causes environmental damage, but also makes people lose their assets and property such as land, houses, ponds, and farmland. This condition makes people Bedono having to start their new life with the condition of the property is reduced. In a religious context, the property of a man's earthly life support that can also deliver them in happiness hereafter. Although not the only aspect, but the ownership of property can be a bridge for Muslims to perform sedakah, zakat (pay alms), pilgrimage, and other social worship (muamalah). In addition, ownership of property can also make Muslims prosperous, independent and empowered. For this reason, the mangrove conservation activities carried out by the Bedono community have a significant influence on the protection of the environment and property as well as improving the quality of life of Muslims in Bedono.

\subsection{Religious Function in Mangrove Conservation Activities}

Religious aspect is not only imprinted in their hearts as a powerful form of faith, but also embodied in people's daily activities Bedono as actualization of faith or their religious beliefs. In relation to mangrove conservation, religious aspect becomes one of the all aspects of human life that motivate people to enable them to carry out their duties and responsibilities as a creature of God. For that, there are some functions of religion that accompanied the mangrove conservation activities in the village Bedono, namely:

\subsubsection{Meta-technological Function}

Religion is a way for humans to hammer away at the life of the immanent and transcendent life. In religion, there are several components such as rituals, scriptures, myths, and morality that have a sacred value that can lead humans to supernatural life. Moreover, religion also be a way for humans to obtain happiness that goes beyond material happiness. According to [19], the ritual as one component of religion is used to introduce supernatural 
powers into natural processes. In this case, people believe that the processes of life they lead is not free from the interference of supernatural power.

In relation to mangrove conservation activities in Bedono Village, the supernatural power is believed to have a stake in it. For those who have planted mangrove trees and some areas have become a dense forest is not the only aspect that can keep them safe from harm Rob. Grace and salvation of God as a supernatural power is most decisive for the sustainability of their life there.

These conditions, the circumstances that led to human life is not just rely on the safety of the technology they have, even if the technology in a very good condition. Furthermore, humans rely on the safety of their lives on the supernatural forces that are behind the technology. In this case, people assume that they have received assistance for the new supernatural aspects that cannot be manipulated in their lives. Religion is used to restore, maintain, or promote important values that they deem to be in danger.

Meta-technological function of this can be seen in a series of rituals, hymns, and prayers by the community Bedono. Although the ritual and prayer are not specifically recited during planting mangrove, but the religious activities regularly carried out by the public Bedono. Routine ritual that was done by people Bedono is tradition of Apitan which is carried out in the wedge, the month that lies between the month of Shawwal and Dzu al-Hijjah in the Islamic calendar. In the past, the tradition of this clamp is filled with sea alms event by slaughtering goats or cows, and her head thrown away (floated) to the sea and a few other foods. This ritual is performed to seek safety. Along with the growing strength of Islamic values they believe, ritual float or sea alms are replaced with the recitation event and prayed together around the coast for the salvation of the Lord.

The various kinds of rituals performed by the Bedono community, ranging from communal rituals such as the apitan tradition, recitation, majelis taklim, and tahlilan as well as personal rituals in the form of prayer and recitation of the Koran are a series of religious activities which are oriented to achieve safety. They are well aware that their ecological conditions are unstable and at any times can be life-threatening. They can inhabit it not just because of the mangrove trees, but also because of the intervention of God. For them, in a grove of mangrove trees, there is a supernatural power, the power of God, which gives a sense of security and safety for them.

\subsubsection{Worship Function}

Beside meta-technological function, the worship is also has a religious function which is to accompanies the activities of Bedono Village community mangrove conservation. In the function of worship, people assume that all their activities are good and provide benefits for others as their form of worship as servants of Allah. According to Trammel, if the function of meta-technology aims to bring the supranatural power into the natural environment, then the function of worship (or in the Trammel's term is called a sacrament function) aims to bring the power of the sacred into the human soul.

As a society based on the values of Islam, people believe that Bedono and rehabilitate mangrove planting is an activity that is worth worship. The value of worship can be seen from the purpose and benefits of planting mangroves for humans. By planting mangrove, they can treat to prevent coastal erosion, caring for the environment while keeping salvation of their souls. Usefulness of mangrove that can be felt by many people, even many species giving importance to the community, which according to public belief Bedono, has a value of reward. 
Therefore, planting mangroves not only provide benefits in the world, but also expect the reward in the hereafter.

The planting of mangroves in the village Bedono was initially very difficult to do. Bring awareness to the community about the benefits of mangrove is not an easy job, because they have not seen the benefits of it before. Therefore, many ways to do so that citizen participation in mangrove conservation can grow, one of them with pengajian and tahlilan. Through this study and tahlilan, public awareness of the importance of mangrove planting can grow, because they can be understood the benefits of mangroves that are not only profane but also sacred.

\section{Conclusion}

As a majority Muslim community, the mangrove conservation activities carried out by the Bedono community cannot be separated from religious motivation. The belief in the reward for rewarding their beneficial worldly activities is a religious basis for their mangrove conservation activities. That is because this activity can have positive implications for the continuity of their lives as human believers as well as their responsibilities as servants of God.

The religious function contained in the Bedono community's activities in conserving mangroves is the function of meta-technology and worship functions. The function of metatechnology can be seen from the beliefs of Bedono people who see that the safety of their lives is not solely due to the lush mangrove forests, but also because of the grace and power of Allah SWT. Meanwhile, the function of worship can be seen from the view of the Bedono people who see that mangrove conservation is a work that is worth of worship, so they can benefit in the world and the reward in the hereafter.

\section{References}

[1] A. A. Khasnis and M. D. Nettleman, "Global warming and infectious disease," Arch. Med. Res., vol. 36, no. 6, pp. 689-696, 2005.

[2] T. P. Hughes et al., "Climate change, human impacts, and the resilience of coral reefs," Science (80-. )., vol. 301, no. 5635, pp. 929-933, 2003.

[3] C. Change, "Climate change," Synth. Rep., 2001.

[4] B. Vatria, "Berbagai kegiatan manusia yang dapat menyebabkan terjadinya degradasi ekosistem pantai serta dampak yang ditimbulkannya," 2013.

[5] N. D. Uar, S. H. Murti, and S. Hadisusanto, "Kerusakan Lingkungan Akibat Aktivitas Manusia pada Ekosistem Terumbu Karang," Maj. Geogr. Indones., vol. 30, no. 1, pp. 88-96, 2016.

[6] R. Novianty, S. Sastrawibawa, and D. J. Prihadi, "Identifikasi kerusakan dan upaya rehabilitasi ekosistem mangrove di Pantai Utara Kabupaten Subang," J. Akuatika, vol. 2, no. 2, 2011.

[7] R. I. Sophian, "Penurunan Muka Tanah di Kota-Kota Besar Pesisir Pantai Utara Jawa (Studi Kasus: Kota Semarang),” Bull. Sci. Contrib., vol. 8, no. 1, pp. 41-60, 2010.

[8] A. S. Ramadhany, P. Subardjo, and A. A. D. Suryo, "Daerah Rawan Genangan Rob di Wilayah Semarang," J. Mar. Res., vol. 1, no. 2, pp. 174-180, 2012.

[9] A. Ismanto, A. Wirasatriya, M. Helmi, A. Hartoko, and P. Prayogi, "Model Sebaran Penurunan Tanah di Wilayah Pesisir Semarang," Int. J. Mar. Sci., vol. 14, no. 4, pp. 189196, 2009.

[10] K. Damaywanti, “Dampak Abrasi Pantai Terhadap Lingkungan Sosial (Studi Kasus di 
Desa Bedono, Sayung Demak," 2013.

[11] B. T. Desmawan and S. Sukamdi, "Adaptasi masyarakat kawasan pesisir Terhadap banjir rob di kecamatan sayung, Kabupaten demak, jawa tengah,” J. Bumi Indones., vol. 1, no. 1, 2012.

[12] Z. Lubis, "Menumbuhkan (kembali) kearifan lokal dalam pengelolaan sumberdaya alam di Tapanuli Selatan," Antropol. Indones., 2014.

[13] H. Hidayat, "Pengelolaan Sumber Daya Alam Berbasis Kelembagaan Lokal J," Sej. CITRA LEKHA, vol. 15, pp. 19-32, 2011.

[14] T. O. S. Aulia and A. H. Dharmawan, "Kearifan lokal dalam pengelolaan sumberdaya air di Kampung Kuta," Sodality J. Transdisiplin Sosiologi, Komunikasi, dan Ekol. Mns., vol. 4, no. 3, pp. 345-355, 2010.

[15] S. M. Awoyemi, A. Gambrill, A. Ormsby, and D. Vyas, "Global efforts to bridge religion and conservation: are they really working?," Ed. by Tony Povilitis, p. 97, 2012.

[16] O. Rusinga and R. Maposa, "Traditional religion and natural resources: A reflection on the significance of indigenous knowledge systems on the utilisation of natural resources among the Ndau People in South-eastern Zimbabwe," J. Ecol. Nat. Environ., vol. 2, no. 9, pp. 201-206, 2010.

[17] C. V. O. Eneji et al., "Traditional African Religion in Natural Resources Conservation and Management in Cross River State, Nigeria," Environ. Nat. Resour. Res., vol. 2, no. 4, p. $45,2012$.

[18] C. Geertz, The religion of Java. University of Chicago Press, 1976.

[19] W. C. Tremmel, Religion, what is It? Holt, Rinehart, and Winston, 1984. 